\title{
The adventures of Miranda in the brave new world: learning in a Web 2.0 millennium
}

\author{
Cameron Barnes* and Belinda Tynan \\ University of New England, Australia
}

This paper looks at the implications of Web 2.0 technologies for university teaching and learning. The latest generation of undergraduates already live in a Web 2.0 world. They have new service expectations and are increasingly dissatisfied with teacher-centred pedagogies. To attract and retain these students, universities will need to rethink their operations. New social technologies mean that universities have the chance to create a new generation of student-centred learning environments, to realize the idea of a University 2.0. The following discussion draws upon a fictional character in order to capture the possible futures of such a brave new world.

\section{Introduction}

Miranda awoke to the latest hit from Beijing Princess at maximum volume. The aging speakers attached to her brother's old Zune Plus did little for the music. Accepting the inevitable, Miranda pointed her iPhone at the Zune. The girl band died, only to be replaced by the audio track from Doom 5.0. Lost in the sound of a Martian apocalypse, Miranda reflected on the disadvantages of a terabyte of storage. It didn't pay to shuffle: you never knew what you might find. A SMS arrived from the University administration reminding Miranda she had a tutorial at 10.00 AM. She hadn't prepared. Time to call Helsinki.

On the other end of the line, Ari, the distance student from Finland patiently explained the question. Caliban. It sounded like a breakfast cereal. Then she remembered. The Shakespeare play. Dispossession. How do you spell that? Yes, she'll send the anime, sorry, this time, she promised.

Miranda is a fictional student at a British University in 2012. Her story, however, is not intended simply as science-fiction. The Web 2.0 social technologies that enable Miranda's world of intertwined personal and educational opportunities already exist in the present day. Undergraduates at universities worldwide are already using these

\footnotetext{
*Corresponding author. Electronic Services Development, University Library University of New England, Armidale NSW 2351, Australia. Email: cbarnes@une.edu.au
} 
technologies in their daily lives. These students have already stepped across a digital divide, leaving behind lecturers still struggling with the implications of the previous generation of Web technologies. If this gap is not to grow wider, we need to rethink the concept of a university: to look towards the goal of a University 2.0. If this discussion raises awareness of this issue, and hints at some of the pragmatic reasons why a University 2.0 is a desirable goal, it will have achieved its purpose. Otherwise, Miranda's world will remain tantalizingly out of reach.

\section{Background}

Few would dispute that the past decade has seen unprecedented innovation in the area of Web-based learning and teaching in higher education (Dede, 2000; Garrison \& Anderson, 2003; Evans et al., 2004; Beetham, 2005; New Media Consortium \& EDUCAUSE, 2006). Despite the growing range of teaching and learning possibilities, adoption has lagged well behind the advances in technology. The traditional lecture remains the dominant method of teaching undergraduate students. Kirkup and Kirkwood have observed that:

teaching staff appropriate those technologies which they can incorporate into their teaching activity most easily, that offer affordances for what they already do, rather than those which radically change teaching and learning practices. (2005, p. 188)

Part of the reason for this conservatism is the extent to which teaching modes in higher education are shaped by convention. University teachers have 'traditionally progressed from the experience of learning in the classroom to teaching in the classroom' (Jamieson, 2004, p. 22). Few of the current generation of teaching staff have been online learners. With some exceptions, teaching staff and the latest cohort of undergraduates live in different technological worlds.

Efforts to bridge this digital divide are often frustrated by competing demands on the time and energies of university teaching staff. Collis observes that:

we must publish; we must obtain research funding and carry out empirical research ... we are evaluated in our teaching on the basis of student satisfaction and course completion ... And yet we are supposed to be educating our own students to become professionals in the new type of educational environments that we do not even know how to demonstrate ourselves. (1998, p. 3)

Even with the best will in the world, many academics are likely to feel that Miranda's world is simply out of reach. They have been left behind.

On the train, Miranda skipped across wireless networks until she found the right podcast. Google Pod was on the money. Miranda was always good with folksonomy. She liked the sound of the South African professor's voice. What did she look like? Don't they have vblogs in South Africa? Miranda felt a little more confident. She despatched the anime to Finland. She was about to disconnect when she remembered that Ari might appreciate the podcast. She sent that too.

At the cafeteria, Miranda played off MS Book Search against Google Books. She switched from one to the other, reading enough criticism to confirm her initial ideas. As she went 
to Project Gutenberg for the text of the play, Miranda's hand brushed her coffee cup, downloading its streaming contents over her keyboard.

In addition to conventional technologies (such as personal computers, the Web and email), students have also embraced mobile technologies. Almost every undergraduate has a digital device of some kind: a mobile phone, PDA, digital camera, iPod or MP3 player. Many have devices that fulfil multiple functions (the iPhone is only the latest example of digital convergence). The extent of this transformation is staggering. A survey of students born after 1980 at the University of Melbourne revealed the following:

- High technology access: $96 \%$ had a mobile phone, $90 \%$ had a desktop computer, $76 \%$ had a digital camera, $69 \%$ had a MP3 player and $63 \%$ had a laptop computer

- The most common uses of computer based activities were: email (94\%), creating documents $(88 \%$ ), playing digital music files (84\%), searching for information (general $83 \%$ and study $76 \%$ ), communicating via instant messaging (80\%)

- Students were also engaging with emerging technologies, including: blogs (reading $38 \%$, commenting $27 \%$, maintaining $21 \%$ ), file sharing (music $38 \%$, photos $31 \%$ ), social networking (24\%), VOIP (19\%) and web-conferencing (19\%). (Kennedy et al., 2006, p. 3)

Studies elsewhere have confirmed the extent of undergraduate involvement in the collaborative, social world of Web 2.0. The tools that Miranda uses so well-wikis, blogs, vlogs (video-blogs), mashups, podcasts, interactive spaces (e.g. MySpace), RSS (Really Simple Syndication) feeds, semantic tagging and folksonomy — are near ubiquitous among the latest generation of young adults (Oblinger, 2007). The passive Web-based learning modes that most academics have yet to adopt are already out of date. If universities are to catch up, then resources, infrastructure, staff development and awareness of new modes of learning need to be radically improved.

Miranda held her breath as she wiped the coffee from her flexible computer. The machine survived. Again, it didn't seem to mind decaf in moderation. Just as well.

At the heart of the Web 2.0 ideal is the notion that the harnessing collective intelligence will yield dividends to organizations as well as consumers. O'Reilly has argued that:

Web 2.0 applications are those that make the most intrinsic advantages of that platform: delivering software as a continually-updated service that gets better the more people use it, consuming and remixing data from multiple sources, including individual users, while providing their own data and services in a form that allows remixing by others, creating network effects through an 'architecture of participation', and going beyond the page metaphor of Web 1.0 to deliver rich user experiences. (2005a)

It is not surprising that Web 2.0 has attracted attention among educational theorists. Hinchliffe (2007) describes it as 'white hot'. The new technologies that enable users to create, search, control and syndicate content hold revolutionary promise for enhancing learning through collaboration and social interactivity (Fumero, 2005). 
The South African professor had referred to an article in a local journal. Miranda hadn't found it anywhere. She'd gone through the university library catalogue, Google Scholar and Windows Live Academic. Nothing. Ari's return email with its collection of podcast links and del.icio.us tags (poor Ari-still using del.icio.us!) gave the answer. Try Jan Szczepanski's list of Open Access Journals at Göteborg. Look for the journal under its initials. She passed Ari's email on to her circle of friends. A few clicks later she was reading the article. She sent that on too. Time for some hot soup.

Miranda's computer survived the soup. Things were looking up.

\section{Facing the issues}

Miranda's world will not come into being without effort. As we have seen, the likelihood is that educators will engage with Web 2.0 technologies in the same old ways. As Kirkup and Kirkwood have shown, teaching staff in higher education will probably employ the latest technologies to teach much as they have done in the past, if left to their own devices. To the extent that, say, podcasting has begun to make an impact in higher education, this has already happened. Most podcasts are last year's lecture in digital format. Student remixing of podcasts, use of syndication to pool collective responses and other more active learning approaches are losing out to those that see podcasting as a high-tech alternative to the audio cassette of the 1980s. To avoid this outcome, university policy-makers and teaching staff alike need to listen to the call for fresh pedagogies, such as connectivism (Siemens, 2005). Teachers can learn from their students. They can design and develop twenty-first-century methods of teaching, instead of hanging onto warmed-over approaches from the past. However, this will not happen unless they are given the time, resources and organizational space to make the attempt.

Why should hard-pressed university administrators take the risk? Is the lecture not still the most cost-effective form of teaching? Although these arguments have prevailed for some time, they are far less relevant in a Web 2.0 world. Failing to make the best use of the new opportunities is not a realistic option. Universities, like other enterprises, now live in a competitive environment. As O'Reilly reminds us

The competitive opportunity for new entrants is to fully embrace the potential Web 2.0. Companies that succeed will create applications that learn from their users, using an architecture of participation to build a commanding advantage not just in the software interface, but in the richness of the shared data. (2005b)

Those universities that are prepared to teach in new ways are likely to win out in the marketplace. The commercialization and internationalization of the university sector in many countries has meant that higher education providers are now far more sensitive to the needs of undergraduates as consumers. Students are also now more discerning in terms of outcomes and the quality of their educational experience.

The traditional lecture is not an appealing product. Most undergraduates have grown up with an anytime, anywhere lifestyle. They complete a range of online social, personal and financial transactions at their convenience. They shop, make friends, sell, communicate, exchange gifts, generate creative works and even make war (if only 
virtually) over the Web. Many find the traditional lecture old-fashioned and boring. Whether due to alternative work or lifestyle commitments, instrumentalist approaches to learning, the availability of alternatives or simply a reduced tolerance for boredom, undergraduate absences from lectures in countries such as the United States, Great Britain and Australia is on the rise. A recent discussion of the literature has concluded that the 'trend towards non-attendance is inevitable' (Massingham \& Herrington, 2006, p. 97). It is clear that a growing number of undergraduates would prefer not to attend lectures if effective online alternatives were available. University policy-makers who would like to secure first-mover advantages might like to take note.

Web 2.0 teaching has other potential benefits for universities. Many universities remain dependent on public funds. Where this is the case, there are signs that taxpayers (or at least the governments that presume to speak for them) are becoming more demanding in terms of performance measures. Those universities that perform worst in terms of grades, attrition rates and graduate skills have found themselves under increasing pressure. Effective use of the new Web 2.0 technologies can reduce the risk of a diminishing spiral of reduced funding, shrinking resources and poorer student outcomes. Not to move ahead means to fall behind.

This argument is strongest in relation to attrition rates. There is abundant evidence that the traditional lecture is not the best form of teaching for weaker students (Goldfinch, 1996; Reynolds, 1997; Boylan \& Saxon, 2005). Those undergraduates who initially fail to make the transition to higher education are often precisely those who have benefited least from these. As Boylan and Saxon observe:

Students in remedial course have been lectured to in the past without much effect. If traditional teaching methods had worked for these students, they would not be taking remedial courses. $(2005$, p. 3)

Active learning strategies, such as those facilitated by Web 2.0 technologies, are likely to be far more effective in the case of such under-prepared students. It makes longterm sense for universities to invest in better teaching. Lowering standards is, of course, still the cheapest option of all, but is unsustainable in the longer term.

Benefits from better teaching are likely to flow on to all students. Once again, the issue is only partly a question of engagement and willingness to change. Equally important is the issue of resources, technical support and institutional flexibility. Not to spend on the development of new approaches is penny wise and pound foolish.

Miranda was the first to arrive. When she walked in, sensors activated the room lights, the air-conditioning and the wall screen. As she unrolled her computer, the room's wireless network connected and launched SkypeVideo. The tutorial began a few minutes later. The tutor and five other students attended in person. Another four connected from Edinburgh, Amsterdam, Helsinki and Vancouver.

Thanks to Miranda and Ari, the class was well-prepared. Within twenty minutes, the desert island of the Tempest had been left behind, Caliban's fate momentarily forgotten. Their tutor plunged the class headfirst into the tangled tickets of literary theory. Miranda was grateful that the tutorial was being recorded. When their tutor referred to Riemann Space in a lengthy explanation of Derrida and deconstruction, the group lost him. Even ten seconds later, when Miranda had looked up the Reimann Space in Google, she was no 
wiser. Ari's question, and the follow-up from Jane in Canada, indicated that incomprehension was transatlantic. The group would need to reconnect after the tutorial and discuss the point.

\section{What of theory?}

Where does Miranda fit into educational theory? Put simply, theory operates on a horizon that extends from behaviourism to constructivism and perhaps to the new connectivism. Behaviourism is based on didactic and transmission-oriented approaches whereby it is the teacher's responsibility to transfer knowledge to students. Students respond to stimuli. Feedback from the teacher informs them whether they are correct. The student is a passive receiver, and the teacher is central to whether learning occurs. The teacher's focus is on 'steering behaviour and not on cognitive steering processes' (Asmus et al., 2005, p. 1). While this approach has fallen out of favour among educational theorists, it remains a standard form of learning in higher education. Lecturers transfer knowledge and tutorials provide students with feedback. Where knowledge is fixed, this form of learning can be reasonably effective, leading to a model of education as a process of transmission, where resources are 'centralized, standardized, and delivered through a top-down method' (Asmus et al., 2005, p. 2). Miranda's world is quite the opposite.

Further along the continuum from behaviourism is cognitivism. This is more concerned with the 'inner processes of the brain seeking to differentiate, investigate and bring these processes together into mutual relation' (Baumgartner, 2005, p. 2). Ally (2004) highlights the focus within cognitivism on the transfer of information by the learner into long-term memory. Cognitivism involves recognition of the fact that students process information through a range of actions, and acknowledges individual differences (Kolb, 1984; Mayer, 1998). Cognitive teaching strategies are therefore responsive to individual learning styles. Like other 'isms', cognitivism draws upon a substantive field of theory; not the least of which are the contributions made by the Russian theorist Vygotskii (1896-1934). However, essentially the teacher remains no more than the controller of the learning environment. He or she facilitates the learning process through a range of learning activities. This is in stark contrast to transfer of an inert, static body of knowledge. Once again, the fit between this model and Miranda's world is inexact. Although Miranda is not totally autonomous, she plays a big part in shaping her learning environment.

Miranda spent the rest of the afternoon in Georgian London. Her history group had been set the task of writing a Wikipedia article on anti-Catholic feeling and the outbreak of the War of Jenkins Ear (1739). Sitting alone in a quiet corner of the university library, Miranda was free to explore the Net. Pulses of light sped across oceans and bounced from city to city, as her group gathered material from libraries and archives. The text of early broadsheets, parliamentary debates and private letters were assembled. Sebastian, from Madrid, provided a running commentary on the Spanish perspective during the countdown to war. No one mentioned Gibraltar. Sebastian had refought the siege of 1779-83 a few weeks earlier. His opponent had been Miranda's brother and Sebastian had won easily. Three times. 
At the far end of the horizon to behaviourism is constructivism, where teachers and their students engage in activities where knowledge is not predetermined. As Laurillard states, it appears to encompass 'all educators who reject the "transmission model" of teaching' (2002, p. 67). According to Baumgartner, constructivism is founded on the idea that 'learning is considered as an active process in which people construct their knowledge by relating it to their previous experiences in complex and real situations in life' (2005, p. 40).

The teacher's role is to be a collaborator in the construction of knowledge. The teacher and student both engage equally in description, explanation, understanding, reflection and disclosure. They provide opportunities for complex information to be interpreted alongside the learner's needs and ways of knowing the world (Burge, 1995). Further:

that in this model of action actors are mutually dependent on one another because they must agree on and coordinate their plans of actions ... The actors try to coordinate their plans of actions by consent and to execute them only under the condition of collectively achieved agreement. (Baumgartner, 2005, p. 10)

Connectivism seems to be emerging as a new educational theory, although it is not without its critics (Verhagen, 2006; Wise \& Quealy, 2006). These claim that connectivism does not go beyond traditional social constructivist theory. Even so, connectivism should be recognized as a valid attempt to develop a theoretical framework that accords with our developing information environment. Siemens (2005) believes that we cannot continue to do as we have done and match traditional models to new tools. The key principles of connectivism are:

- learning and knowledge rests in diversity of opinions;

- learning is a process of connecting specialized nodes or information sources;

- learning may reside in non-human appliances;

- capacity to know more is more critical than what is currently known;

- nurturing and maintaining connections is needed to facilitate continual learning;

- ability to see connections between fields, ideas, and concepts is a core skill;

- currency (up-to-date knowledge) is the intent of all connectivist learning activities; and

- decision-making is itself a learning process. Choosing what to learn and the meaning of incoming information is seen through the lens of shifting reality. While there is a right answer now, it may be wrong tomorrow due to alterations in the information climate affecting the decision.

Connectivism, like social constructivist theory, sees the role of the teacher as one of mediator. The key idea is that learning starts with the connections that students make and not with a fixed body of content. Here Miranda's world comes into sharp focus.

Miranda's world is not without its problems. If we are to move towards a Web 2.0 model, the higher education community also needs to take into account the issues raised by Crie (2004). Crie alerts us that access, security and free expression need to 
be considered carefully in relation to issues of privacy, freedom of information and student safety. Not all students will want to engage with new social technologies as part of their education. Others may see participation as an erosion of their autonomy, constricting rather than empowering. Miranda may be confident and assured, but this attitude cannot be assumed.

The group had agreed that they would create an audio podcast after they had finished the Wikipedia article. Katalin, from Dublin, had assembled audio clips of waves, cannon-fire and creaking timbers. Jim, a Londoner, had God Save the King sung in lusty chorus on CD. According to Google the song was a little late (1744). Rule, Britannia! (1740) was fine, if put in towards the end. Jim's father, a barrister, would deliver lines from speeches by Sir Robert Walpole. Sebastian would stand-in for the Spanish ambassador, anxiously writing back to Madrid. They were only lacking a blood-curdling scream for the moment when Captain Jenkins and his ear parted company. Miranda's brother was looking through his game collection. Screams were usually not a problem.

Once completed, the podcast would be posted on the Net. Miranda hoped it might remind people that wars fought on thin pretexts were always a mistake. Like wars in general.

There are other important issues to address. Miranda and her varied classmates may be an exception. In the real world, undergraduates often lack life experience. There is a danger that all individuals in the same group will share the same limited perspectives. Groups need to be aware of subtle vetting processes that can produce conformity. Another risk is that content can be filtered through aggregation.

A further problem is that user-selected content may not be reliable. Without traditional gatekeepers, such as librarians, students will need to learn how to evaluate information. Users of folksonomies may be at home in their own online environments. They must also engage with more formal methods of labelling the world if they are to become effective searchers. Librarians and professional researchers use controlled vocabularies for a purpose, even if their rationale seem mysterious to most students (Asmus et al., 2005).

\section{University 2.0}

Miranda's teachers will have access to a sophisticated set of technologies for use in the online learning environment. However, they need to be careful not to make rash assumptions about how she uses these tools. If they do, Miranda's interest might wander, particularly if their assumptions seem common-place or unimaginative. Miranda's competence in the use of Web 2.0 technologies in her private life has clearly spilled over into her learning. But will all students be as capable? If they are not, what strategies will teaching staff use to assist? Miranda's diary provides us with some warnings, as well a range of possibilities for new models of learning.

The width of the digital divide will depend on more than the capacity of teachers to depart from traditional forms of instructions. University policy-makers must also consider how to enable and support students such as Miranda. Just how committed are institutions to flexibility and responsiveness when it comes to administrative and technical functions? Web 2.0 requires a conceptual response that differs from business 
as usual. Most undergraduates now expect the same level of service from university administrations that they receive from their ISP or mobile phone provider. If they are not happy with a provider, they switch.

How does all this work in practice? How can universities and shrinking budgets engage with the demands of connectivism? To begin to answer this question, we must first consider just how archaic universities must appear to many students. As a method of teaching, the traditional lecture is far older than the first universities (which appeared in the twelfth century). Yet it remains the cornerstone of undergraduate education in the twenty-first century.

The absurdity is that the most modern lecturers lack any grounding in formal rhetoric, once an essential part of the medieval trivium. By mediaeval standards, today's university lecturers (with the exception of those in education and related disciplines) are untrained amateurs in the art of oral presentation. The pretence that university experience and research output qualify a lecturer to teach is as transparently false now as it was two decades ago (Penner, 1984).

How might lectures be delivered in the future? In Miranda's world, the only lectures that students hear are delivered by academics who are able to use the medium to its best advantage. Miranda, like many students in her day, does not attend lectures in person. Instead, her lectures are delivered as podcasts and streamed over the Web. These are not recorded in a lecture hall, but under studio conditions. Consortia of universities exist that federate the best podcasts so as to reduce duplication of effort. The rationale for such consortia is obvious. Many universities now teach out of the same textbooks and, for many undergraduate courses, content does not vary significantly from one university to another (at least within the same country). Universities already share online learning objects; the sharing of lectures is simply another step.

Equally significant is the way in which Miranda makes use of these podcasts. Her teachers use them as the basis for a more active, student-centred approach to learning. Miranda and her peers do not need to rely on their own note-taking. They can replay the lectures any time they like. If they are uncertain at any point, they can pause and rerun the recording. More importantly, access to mobile technologies means that students can annotate the recording, and send their comments on to other learners. They can interrogate each other and share understandings.

University 2.0 is not simply a collection of technologies. Like Web 2.0, it is primarily a concept, a way of thinking. A university in Miranda's world is a place where informal and formal learning occurs, initially over the course of a degree, but ultimately over a lifetime. Miranda participates in parallel communities where personal, educational and professional life lines blur. Miranda participates fully in her educational experiences by cooperating with others to build experiences within an 'architecture of participation' (O'Reilly, 2005a). The university acts as a service provider that 'harnesses the power of the users themselves' (O'Reilly, 2005b).

Miranda, like her present-day peers, creates content and forms part of the dynamic Web. The difference is that Miranda employs these social technologies in ways relevant to her study. To do so, she needs seamless access to the university's administrative and technical infrastructures. If University 2.0 means harnessing the collective 
intelligence of an institution for the benefit of learners, it is up to universities to make their resources more accessible. A visit to almost any university web site reveals just how far institutions are from such an ideal.

Crucial to the concept of University 2.0 is the realization that universities must abandon the idea that they are custodians of a fixed body of knowledge. Miranda and her peers are trusted to seek out, organize and evaluate information in a world in which knowledge is growing at an explosive rate. What is regarded as true today may not be so tomorrow. Miranda's teachers respond to the way in which students engage in an environment of constant intellectual change. They are guides and facilitators, not inerrant sages. University 2.0 will value teachers who place active learners like Miranda at the centre of their work.

\begin{abstract}
Miranda spent the night at her flat. She had logged onto the university's student space, intending to upload some digital pictures, when she found a new link on her page. The link invited her to contact a new student at the university, a boy from her home town: Bridgetown, Barbados. From the photograph posted on his profile, quite a good-looking one at that. Miranda's face broke into grin, as she started typing. Shakespeare might have to wait till tomorrow.
\end{abstract}

\title{
Conclusion
}

This discussion has drawn attention to some of the issues associated with Miranda's brave new world. The most important of these is the need to rethink teaching and learning within higher education. University teaching has fallen behind changes in social technologies. Whereas universities are still struggling to assimilate the first wave of Web-based teaching tools, an increasing number of students have already arrived in a Web 2.0 world. To meet the needs of these students, universities must reconsider their priorities. The latest social technologies have the potential to deliver truly student-centred learning environments, to create a University 2.0. However, this will not happen overnight or without sustained effort.

This paper ends with a call to develop alternative ways of viewing university learning and to rethink the concept of a university itself. Such a discussion must involve all those working within the higher education sector, particularly the decision-makers who shape institutional policies on teaching and learning. The authors do not presume to provide the answers. Miranda's narrative is intended to do no more than provoke, to open the door to new ways of thinking. And there is no time like the present. Social technologies are already shaping the private and social worlds of millennium students. The task for educators and policy-makers is to bridge the existing digital divide before it becomes wider, and a generation of opportunities is lost.

\section{References}

Ally, M. (2004) Foundations of educational theory for online learning, in: T. Anderson \& F. Elloumi (Eds) Theory and practice of online learning (Athabasca, Athabasca University), 3-31. 
Asmus, J., Bonner, C., Esterhay, D., Lechner, A. \& Rentfrow, C. (2005) Instructional design technology trend analysis. Available online at: http://elgg.net/collinb/files/1136/2967/Trend AnalysisWeb.pdf (accessed 13 March 2007).

Baumgartner, P. (2005) The zen art of teaching communication and interactions in eEducation. Available online at: http://www.elearningeuropa.info/extras/pdf/zenartofteaching.pdf (accessed 10 October 2006).

Beetham, H. (2005) E-learning research: emerging issues?, ALT-f, Research in Learning Technology, 13(1), 81-89.

Boylan, H. R. \& Saxon, D. P. (2005) What works in remediation: lessons from 30 years of research. Available online at: http://www.ncde.appstate.edu/reserve_reading/what_works.htm (accessed 1 December 2006).

Burge, L. (1995) Electronic highway or weaving loom?, in: F. Lockwood (Ed.) Open and distance learning today (London, Routledge), 151-163.

Collis, B. (1998) Implementing innovative teaching across the faculty via the www. Available online at: http://education2.edte.utwente.nl/teletophomepage.nsf/\$DefaultView/36EF8F34F88A53 C9412566C7003429D1/\$file/site.doc (accessed 10 October 2006).

Crie, M. (2004) Using blogs to integrate technology in the classroom. Available online at: http://www. glencoe.com/sec/teachingtoday/educationupclose.phtml/print/47 (accessed 26 February 2007).

Dede, C. (2000) Emerging technologies and distributed learning in higher education, in: D. Hanna (Ed.) Choices and challenges (New York, Atwood), 71-92.

Evans, D. L., Bond, P. J. \& Mehlman, B. P. (2004) 2020 vision. Available online at: http:// www.ta.doc.gov/OYPolicy (accessed 15 February 2005).

Fumero, A. (2005) Blogs and the next generation web. Available online at: http://comodios. blogspot.com/2005/09/blogs-and-next-generation-web.html (accessed 25 November 2006).

Garrison, D. R. \& Anderson, T. (2003) E-learning in the 21st century: a framework for research and practice (London, RoutledgeFalmer).

Goldfinch, J. (1996) The effectiveness of school-type classes compared to the traditional lecture/ tutorial method for teaching quantitative methods to business students, Studies in Higher Education, 21(2), 207-220.

Hinchcliffe, D. (2007) How Web 2.0 works. Available online at: http://web2.wsj2.com/howweb 2works.htm (accessed 26 February 2007).

Jamieson, P. (2004) The university as workplace: preparing lecturers to teach in online environments, Quarterly Review of Distance Education, 5(1), 21-27.

Kennedy, G., Krause, K., Judd, T., Churchward, A. \& Gray, K. (2006) First year students' experiences with technology: Are they really digital natives? Available online at: http://www.bmu. unimelb.edu.au/research/munatives/natives_report2006.pdf (accessed 14 March 2007).

Kirkup, G. \& Kirkwood, A. (2005) Information and communications technologies (ICT) in higher education teaching - a tale of gradualism rather than revolution, Learning Media and Technology, 30(2), 185-199.

Kolb, D. A. (1984) Experiential learning: experience as the source oflearning and Development (Englewood Cliffs, NJ, Prentice-Hall).

Laurillard, D. (2002) Rethinking university teaching: a framework for effective use of learning technologies (London, Routledge).

Massingham, P. \& Herrington, T. (2006) Does attendance matter? An examination of student attitudes, participation, performance and attendance, fournal of University Teaching and Learning Practice, 3(2), 82-103.

Mayer, R. E. (1998) Cognitive, metacognitive, and motivational aspects of problem solving, Instructional Science, 26(1-2), 49-63.

New Media Consortium \& EDUCAUSE (2006) The horizon report (Austin, TX, EDUCAUSE).

Oblinger, D. G. (2007) Listening to what we're seeing. Available online at: http://www.informationonline.com.au/docs/Presentations/info_online_2007_v6-ho.pdf (accessed 14 March 2007). 
O'Reilly, T. (2005a) Web 2.0: Compact definition? Available online at: http://radar.oreilly.com/ archives/2005/10/web_20_compact_definition.html (accessed 14 March 2007).

O'Reilly, T. (2005b) What is Web 2.0: design patterns and models for the next generation software. Available online at: http://www.oreilly.com (accessed 23 November 2006).

Penner, J. G. (1984) Why many college teachers cannot lecture: how to avoid communication breakdown in the classroom (Springfield, IL, C. C. Thomas).

Reynolds, F. (1997) Studying psychology at degree level: would problem-based learning enhance students' experiences, Studies in Higher Education, 22(3), 263-275.

Siemens, G. (2005) Connectivism: a learning theory for a digital age. Available online at: http:// www.elearnspace.org/Articles/connectivism.htm (accessed 24 November 2006).

Verhagen, P. (2006) Connectivism: A new learning theory? Available online at http://elearning.surf. nl/e-learning/english/3793 (accessed 1 August 2007).

Wise, L. \& Quealy, J. (2006) At the limits of social constructivism: moving beyond LMS to reintegrate scholarship, paper presented at the $23^{\text {rd }}$ Annual ASCILITE Conference: Who's learning? Whose technology? Available online at: http://www.ascilite.org.au/conferences/sydney06/ proceeding/pdf_papers/p158.pdf (accessed 1 August 2007). 